\title{
Reclaiming the Human Rights Foundations of the UN Standards of Conduct for Business on Tackling Discrimination against LGBTI People
}

\author{
Amanda Lyons $^{1 *}$ (D) and Cooper Christiancy ${ }^{2}$ \\ ${ }^{1}$ Amanda Lyons is Executive Director at the Human Rights Center at the University of Minnesota Law \\ School, USA \\ ${ }^{2}$ Cooper Christiancy is a Research Fellow at the Human Rights Center at the University of Minnesota \\ Law School, USA \\ *Corresponding author; Email: lyon0061@umn.edu
}

\begin{abstract}
The business and human rights field and the international LGBTI human rights agenda have evolved almost entirely separately. The United Nations 'Standards of Conduct for Business on Tackling Discrimination against LGBTI People' (2017) is the primary effort to bridge this gap. Although drafted in a way that strongly aligns with the second pillar of the United Nations Guiding Principles on Business and Human Rights on corporate responsibility, the dissemination of the Standards has mainly been untethered from the human rights framework and system. This article identifies the need to reassert the human rights foundations of the Standards and leverage their existing momentum to set out a more robust research and policy agenda for meaningfully accounting for sexual orientation, gender identity and expression, and sex characteristics in business and human rights frameworks. To that end, the article sets out priority areas for greater attention from researchers, decision-makers and advocates.
\end{abstract}

Keywords: corporate social responsibility; LGBTI; sexual orientation and gender identity; UN Guiding Principles; UN Standards of Conduct

\section{Introduction}

On 17 June 2011, the United Nations (UN) Human Rights Council broke ground on a new agenda in the international human rights system - human rights, sexual orientation and gender identity (SOGI). ${ }^{1}$ A hard-fought vote paved the way for a cascade of advances in the international recognition and protection of the human rights of lesbian, gay, bisexual, transgender and intersex (LGBTI) people. ${ }^{2}$ The day before, on 16 June 2011, the Council had formally established another framework - endorsing the UN Guiding Principles on Business and Human Rights (UNGPs) and creating the UN Working Group on Business and Human Rights (UNWG). ${ }^{3}$

\footnotetext{
${ }^{1}$ Human Rights Council, 'Human Rights, Sexual Orientation and Gender Identity', A/HRC/RES/17/19 (14 July 2011).

${ }^{2}$ Office of the High Commissioner for Human Rights, 'Born Free and Equal: Sexual Orientation, Gender Identity and Sex Characteristics in International Human Rights Law’, HR/PUB/12/06/Rev.1 (2019) 14.

${ }^{3}$ Human Rights Council, 'Human Rights and Transnational Corporations and Other Business Enterprises', A/HRC/RES/17/14 (6 July 2011).

(c) The Author(s), 2022. Published by Cambridge University Press. This is an Open Access article, distributed under the terms of the Creative Commons Attribution licence (http://creativecommons.org/licenses/by/4.0), which permits unrestricted re-use, distribution and reproduction, provided the original article is properly cited.
} 
Despite the coincidental timing of these pivotal resolutions, the LGBTI human rights agenda and the business and human rights (BHR) field have evolved almost entirely separately over the last decade. This article explores the most significant effort to bridge this gap: the 2017 Office of the High Commissioner for Human Rights (OHCHR) publication, 'Tackling Discrimination against LGBTI People: Standards of Conduct for Business' (Standards). ${ }^{4}$ There has been almost no scholarly engagement with this critical resource and related initiatives ${ }^{5}$ and no scholarship exploring the SOGI dimensions of BHR frameworks whether the UNGPs, efforts at the national and regional levels, or the process for a new binding legal instrument.

The Standards are intended to 'offer practical guidance to companies on how to respect and support the rights of LGBTI people in the workplace, marketplace and community.' ${ }^{6}$ $\mathrm{OHCHR}$ declares that the publication is 'essential reading for anyone interested in the role of the private sector in respecting and promoting the fundamental human rights of LGBT and intersex people." The Standards are grounded in the international human rights framework ${ }^{8}$ and offer a rich analysis of how the UNGPs, specifically Pillar 2 on the corporate responsibility to respect, ought to apply to the human rights of LGBTI people in the context of business activities.

Although the responsibility to respect the rights of LGBTI people 'applies regardless of the company size, structure, sector, or location', 9 the Standards emerged as part of a distinct line of developments related to the increased attention on the role of 'global business' (i.e., multinational corporations headquartered in the Global North) to champion LGBTI equality around the world. Despite the strong human rights foundations in the document, the promulgation of the Standards has been dominated by a largely voluntary corporate social responsibility (CSR) approach untethered from the human rights framework and system.

This article emerges from our research and advocacy related to the Standards at the University of Minnesota Human Rights Center, in partnership with the Human Rights Litigation and International Advocacy Clinic. In 2018 we partnered with OHCHR to present the Standards to business leaders and employee resource groups in Minnesota. We have since conducted a wide range of interviews, including with representatives of OHCHR, the Partnership for Global LGBTI Equality (PGLE), participants in the consultations before and after the publication of the Standards, executive leadership of companies in the Global North who have endorsed the Standards as well as several who have declined to do so, leaders of regional and industry-specific business sector LGBTI equality initiatives, experts with the International Labour Organization and human rights entities, and LGBTI rights advocates

\footnotetext{
${ }^{4}$ Office of the High Commissioner for Human Rights, 'Tackling Discrimination against Lesbian, Gay, Bi, Trans, \& Intersex People: Standards of Conduct for Business' (2017), https://www.unfe.org/wp-content/uploads/2017/09/ UN-Standards-of-Conduct.pdf (accessed 27 August 2021) (the Standards).

${ }^{5}$ Gabriel Coutinho Galil, Rafael Carrano Lelis and Paola Durso Angelucci, 'The Inclusion of LGBTI Persons Protection in the International Business and Human Rights Agenda' (2019) 3 International Journal on Human Rights and Business 175 [in Portuguese]; see also Dan Bross, Fabrice Houdart and Salil Tripathi, drafters and champions of the Standards, introduced the initiative in a 'Developments in the Field' piece: 'None of Their Business? How the United Nations is Calling on Global Companies to Lead the Way on Human Rights of LGBTI People' (2018) 3:2 Business and Human Rights Journal 271.

${ }^{6}$ The Standards, note 4, 4.

${ }^{7}$ Office of the High Commissioner for Human Rights, 'Standards of Conduct for Business on Tackling Discrimination Against LGBTI People', https://www.ohchr.org/EN/Issues/Discrimination/Pages/Biz4LGBTI.aspx (accessed 31 October 2020).

8 The Standards, note 4, 3.

${ }^{9}$ Ibid.
} 
working at the local, national and international levels. We have tracked the references to the Standards in human rights mechanisms and procedures and have compiled and assessed information about the 304 companies that have expressed support for the Standards at the time of our writing. ${ }^{10}$

Through an analysis of the Standards, this article contributes to a more robust, rightsbased research and policy agenda at the intersection of sexual orientation, gender identity and expression, and sex characteristics (SOGIESC) and BHR. Fully considering the gender dimensions of BHR requires a lens attuned to how patriarchal power structures and gendered social constructs produce violence and discrimination along the lines of SOGIESC, and particularly how that discrimination intersects with other forms of structural marginalization related to race, gender and class.

The article proceeds as follows. Part II describes briefly the scope of challenges, impacts and opportunities related to business and the human rights of LGBTI persons. Part III differentiates between the range of approaches under the general banner of 'CSR' and those grounded explicitly in human rights, and then explores how these strands have or have not addressed the intersection of business and the rights of LGBTI persons. Part IV analyses the Standards, finding that although the document's design has strong human rights gravitas, its roll-out and uptake has been dominated by a more amorphous CSR approach, primarily untethered from the UN human rights architecture. Part V asserts the importance of a more robust, rights-based engagement on questions of SOGIESC in the broader BHR framework and sets out priority areas for greater attention from researchers, decision-makers and practitioners to reclaim and leverage the human rights foundations of the Standards. Part VI concludes.

Throughout this article, we use the label 'LGBTI' - largely because it is the term used by the Standards. However, we recognize that the acronym's descriptive power is imperfect. ${ }^{11}$ Not everyone discriminated against on the basis of SOGIESC self-identifies under the LGBTI umbrella, and 'local identity labels may also be imbued with cultural significance that is lost when replaced by the LGBT acronym. ${ }^{12}$ Notably, SOGIESC is the preferred term used in the international human rights framework; ${ }^{13}$ this framing better supports an interrogation of how patriarchal norms and constructed genders punish social and sexual non-conformity through violence and discrimination, as well as how this discrimination intersects with other forms of oppression and exclusion. The diversity of lived experiences within global LGBTI communities results in biases and dramatic inequalities in terms of which people and which priorities are captured under the most visible LGBTI human rights and equality banners. ${ }^{14}$

\section{Business, Human Rights and SOGIESC}

Millions of people around the world face systemic discrimination and violence because of their actual or perceived sexual orientation, gender identity/expression or sexual

\footnotetext{
${ }^{10}$ The list of Supporters is available on the website of the Partnership for Global LGBTI Equality, 'The Supporters', https://www.global-lgbti.org/the-supporters (accessed 27 August 2021).

${ }^{11}$ See Holning Lau, 'Sexual Orientation and Gender Identity Discrimination' (2018) 2:2 Brill Research Perspectives in Comparative Discrimination Law 1, 4.

${ }^{12}$ Ibid.

${ }^{13}$ For example, Human Rights Council, 'Report of the Independent Expert on Protection against Violence and Discrimination based on Sexual Orientation and Gender Identity’, A/HRC/38/43 (11 May 2018).

${ }^{14}$ See generally Libby Adler, Gay Priori (Durham: Duke University Press, 2018).
} 
characteristics. ${ }^{15}$ The consequences include systemic social and economic marginalization ${ }^{16}$ and severe physical and mental health consequences. ${ }^{17}$

Pervasive private and state-sponsored ${ }^{18}$ violence continues despite important advances. In fact, some have observed a "backlash'19 against advances of the LGBTI human rights agenda and to the so-called 'gender ideology'. ${ }^{20}$

This systemic violence and discrimination is suffered disparately and differentially by particular groups, as SOGIESC intersect with other forms of discrimination, including 'age, colour, caste, class, race, ethnicity, religion, language, literacy, access to economic resources, marital status, disability, residence in a rural location, and migration, indigenous, or minority status. ${ }^{21}$ Although the transnational LGBTI movement has employed 'strategic essentialism $^{22}$ to build an advocacy coalition, there remain stark differences in lived experiences among LGBTI people. ${ }^{23}$ The erasure of these differences creates generic assumptions about LGBTI life that obscure the lived experiences of the most marginalized groups and in places beyond the Global North. ${ }^{24}$

\section{Adverse Business-Related Human Rights Impacts}

Adverse business-related human rights impacts occur in the workplace and the community. Workplace SOGIESC-related harms include discrimination in recruitment, hiring, retention, promotion, pay and benefits; as well as discriminatory conditions including lack of accommodation, harassment and gender-based violence. ${ }^{25}$ Transgender people face unique challenges at work: inappropriate identification documents, disregard for chosen names, pronouns and gender markers; a lack of gender-appropriate accommodation; and escalated

\footnotetext{
${ }^{15}$ See Human Rights Council, note 13.

${ }^{16}$ UN General Assembly, 'Report of the Independent Expert on Protection against Violence and Discrimination based on Sexual Orientation and Gender Identity', A/74/181 (17 July 2019).

17 Ibid, paras 19-26.

${ }^{18}$ Lucas Ramon Mendos, State-Sponsored Homophobia 2019, 13th edn (Geneva: International Lesbian, Gay, Bisexual, Trans and Intersex Association, 2019).

19 Lynare Robbins, 'EXCLUSIVE: New UN LGBTI Watchdog Talks Global Progress, Backlash', Washington Blade (5 November 2018), https://www.washingtonblade.com/2018/11/05/exclusive-new-un-lgbti-watchdog-talksglobal-progress-backlash/ (accessed 31 October 2020). This backlash has likewise greatly impacted advocacy for women's human rights in general. For example, see the Position Paper by Ivana Radačić and Alda Facio, Mandate of the Working Group on Discrimination Against Women and Girls, 'Gender Equality and Gender Backlash' (2020), https://www.ohchr.org/EN/Issues/Women/WGWomen/Pages/GenderEqualityandBacklash.aspx (accessed 18 August 2021).

20 Judith Butler, 'Judith Butler: The Backlash Against “Gender Ideology” Must Stop', New Statesman (21 January 2019), https://www.newstatesman.com/2019/01/judith-butler-backlash-against-gender-ideology-must-stop (accessed 31 October 2020).

${ }^{21}$ UN Working Group on Business and Human Rights, 'Gender Dimensions of the Guiding Principles on Business and Human Rights' (2019), https://www.ohchr.org/Documents/Issues/Business/Gender_Booklet_Final.pdf (Gender Guidance) 6.

${ }^{22}$ Gayatri Chakravorty Spivak, The Post-Colonial Critic: Interviews, Strategies, Dialogue (London: Routledge, 1990), cited in Banu Ozkazanc-Pan, 'CSR as Gendered Neocoloniality in the Global South' (2019) 160 Journal of Business Ethics 859.

${ }^{23}$ Ibid, 853; see also Lau's discussion of 'queer diaspora', note 11, 42.

${ }^{24}$ Hakan Seckinelgin, 'Same-Sex Lives Between the Language of International LGBT Rights, International Aid, and Anti-Homosexuality’ (2018) 18:3 Global Social Policy 284, 294-97.

${ }^{25}$ See, e.g., International Labour Organization, Discrimination at Work on the Basis of Sexual Orientation and Gender Identity: Results of the ILO's PRIDE Project (Geneva: ILO, 2015).
} 
harassment and abuse. ${ }^{26}$ Workplace abuses especially imperil those LGBTI people in the most precarious positions within an organization's hierarchy. ${ }^{27}$ Systematic exclusion and discrimination contribute to economic and health insecurity, limited social security later in life, and an over-representation of LGBTI persons among those living in poverty globally. ${ }^{28}$ Within the LGBTI population, higher incomes are disproportionately allocated along lines of gender, race and cisgender identity. ${ }^{29}$

Although they receive less attention, there are also distinct patterns of adverse businessrelated human rights impacts along lines of SOGIESC outside of the workplace, including the specific targeting of LGBTI people through harmful activities such as conversion 'therapy' and marketing campaigns. ${ }^{30}$ Violence, discrimination and inequality in the provision of services related to human rights may implicate private actors, including in the areas of education, health, housing, and water and sanitation. ${ }^{31}$ Discrimination in consumer goods and other services is another flashpoint. ${ }^{32}$

LGBTI individuals also suffer differentially or disproportionately from other patterns of abuses: including violence by private security; ${ }^{33}$ infringements on privacy; ${ }^{34}$ failure to regulate hate speech; freedom of expression; ${ }^{35}$ abuses in detention facilities; ${ }^{36}$ human trafficking; ${ }^{37}$ and biased representation through media. ${ }^{38}$ In relation to all human rights abuses and impacts, people may face unique barriers to seeking remedy based on their real or perceived SOGIESC. ${ }^{39}$

\section{B. Business as Ally and Agent of Change}

The world's largest businesses, particularly those headquartered in the Global North, are increasingly assuming, or asked to consider assuming, the role of ally and agent of change

\footnotetext{
${ }^{26}$ See, e.g., IACHR, 'Violence against LGBTI Persons', OAS/Ser.L/V/II.rev.1Doc. 36 (12 November 2015), para 372; Michelle Dietert and Dianne Dentice, 'Gender Identity Issues and Workplace Discrimination: The Transgender Experience' (2009) 14:1 Journal of Workplace Rights 121.

27 Amie Bishop, Vulnerability Amplified: The Impact of the COVID-19 Pandemic on LGBTIQ People (New York: OutRight Action International, 2020) 17, 21, 31.

${ }^{28}$ See generally Victor Madrigal-Borloz, 'The Price that is Paid: Violence and Discrimination based on Sexual Orientation and Gender Identity and Poverty' in Martha F Davis, Morten Kjaerum and Amanda Lyons (eds.), Research Handbook on Human Rights and Poverty (Cheltenham: Edward Elgar, 2021) 171.

${ }^{29}$ MV Lee Badgett, Soon Kyu Choi and Bianca DM Wilson, LGBT Poverty in the United States: A Study of Differences between Sexual Orientation and Gender Identity Groups (Los Angeles: Williams Institute, 2019) 14.

${ }^{30}$ CDC, 'Lesbian, Gay, Bisexual, and Transgender Persons and Tobacco Use', https://www.cdc.gov/tobacco/ disparities/lgbt/index.htm (accessed 7 May 2021).

${ }^{31}$ See, e.g., UN General Assembly, note 16.

32 For example, Masterpiece Cakeshop, Ltd. v Colorado Civil Rights Commission 138 S Ct 1719 (2018).

33 General Assembly, 'Report of the Working Group on the Use of Mercenaries as a Means of Violating Human Rights and Impeding the Exercise of the Right of Peoples to Self-Determination: The Gendered Human Rights Impacts of Private Military and Security Companies', A/74/244 (29 July 2019).

${ }^{34}$ See Article 19, 'LGBTQ Online Summary Report: Apps, Arrests and Abuse in Egypt, Lebanon and Iran' (February 2018), https://www.article19.org/wp-content/uploads/2018/02/LGBTQ-Apps-Arrest-and-Abuse-report_22.2.18.pdf (accessed 23 August 2021).

35 See 'Hate Speech in the Digital World a “Critical Obstacle for LGBTI People”: UN's Bachelet', UN News (24 September 2019), https://news.un.org/en/story/2019/09/1047322 (accessed 31 October 2020).

${ }^{36}$ See Jason A Brown and Valerie Jenness, 'LGBT People in Prison: Management Strategies, Human Rights Violations, and Political Mobilization', Oxford Criminology and Criminal Justice Research Encyclopedia (2020).

${ }^{37}$ Omar Martinez and Guadalupe Kelle, 'Sex Trafficking of LGBT Individuals: A Call for Service Provision, Research, and Action' (2013) 42:4 International Law News 1.

${ }^{38}$ See Haley E Solomon and Beth Kurtz-Costes, 'Media's Influence on Perceptions of Trans Women' (2018)

15 Sexuality Research and Social Policy 1.

${ }^{39}$ Mendos, note 18.
} 
for social and environmental causes. ${ }^{40}$ There is increased attention in the human rights field to the role that business might play as champion for groups that may experience heightened barriers to the realization of their rights such as LGBTI people, women, children and human rights defenders. ${ }^{41}$

In particular contexts, businesses have been called on to act in the public sphere as champions for LGBTI inclusion, although this role remains controversial. ${ }^{42}$ Recent examples include the mobilization of corporate actors in opposition to the North Carolina (US) 'Bathroom Bill' targeting transgender people; ${ }^{43}$ a French retailer's withdrawal of advertising from a Polish state news website in response to Poland's anti-LGBTI policies; ${ }^{44}$ and an alliance of multinational and Brazilian corporations speaking out against anti-LGBTI rhetoric in the lead-up to the election of Jair Bolsonaro. ${ }^{45}$ Corporate allyship may appear particularly appealing for a community that has not historically found protection in the state, supranational human rights actors or religious organizations. Although opinions and positions vary, the advocates with whom we spoke in Jamaica, Colombia, Brazil and Argentina identified multinational corporations operating in their countries to be powerful potential allies in advancing advocacy goals.

Businesses may signal their support for LGBTI equality and inclusion for a variety of reasons, including competitive recruitment pressures, consumer opinions, and often the advocacy of a single individual or small group in the business leadership. ${ }^{46}$ We see businesses in the Global North, and increasingly those in particular countries in the Global South, doing this in six main ways:

- Supportive work environments: In addition to eradicating diverse forms of workplace discrimination, many businesses take steps to proactively support and celebrate diversity in their company culture, and they may also provide LGBTI-inclusive medical or parental benefits not otherwise mandated by public regulations. A main component of this goal can be the creation of LGBTI employee resource groups and internal recognition. ${ }^{47}$

- Value chain diversity and inclusion (D\&I): Beyond leveraging relationships to eliminate discrimination, businesses may proactively support LGBTI-owned business partners. ${ }^{48}$

\footnotetext{
${ }^{40}$ For example, 'Business Roundtable Redefines the Purpose of a Corporation to Promote "An Economy That Serves All Americans”, Business Roundtable (19 August 2019), https://www.businessroundtable.org/business-round table-redefines-the-purpose-of-a-corporation-to-promote-an-economy-that-serves-all-americans (accessed 7 May 2021).

${ }^{41}$ For example, Soledad García Muñoz, ‘Empresas y Derechos Humanos: Estándares Interamericanos' OEA/Ser.L/ V/II (1 November 2019), para 315; Bennett Freeman et al, 'Shared Space Under Pressure: Business Support for Civic Freedoms and Human Rights Defenders' (2018), https://media.business-humanrights.org/media/documents/ fdfe07e3d812cfcfed4235fbbf820a3d77599b13.pdf (accessed 27 August 2021).

42 See Carlos A Bell, Queering Corporate America (Boston: Beacon Press, 2019) 204-05.

43 “"Bathroom Bill” to Cost North Carolina \$3.76 Billion', CNBC (27 March 2017), https://www.cnbc.com/2017/ 03/27/bathroom-bill-to-cost-north-carolina-376-billion.html (accessed 31 October 2020).

${ }^{44}$ Matthew Holroyd, 'Carrefour Withdraws Advertising Campaign from Polish News Website Over LGBT Rights', EuroNews (27 November 2020), https://www.euronews.com/2020/11/27/carrefour-withdraws-advertising-cam paign-from-polish-news-website-over-lgbt-rights (accessed 7 May 2021).

${ }_{45}$ Out and Equal, 'Carta de Apoio à Diversidade, ao Respeito e à Inclusão de Pessoas LGBT+ nos Locais de Trabalho no Brasil', https://outandequal.org/lgbtqbrazil/ (accessed 7 May 2021).

${ }^{46}$ Cory Maks-Solomon and Josiah Mark Drewry, 'Why Do Corporations Engage in LGBT Rights Activism? LGBT Employee Groups as Internal Pressure Groups' (2021) 23:1 Business and Politics 124.

${ }^{47}$ See Bell, note 42, 112-17.

${ }^{48}$ Human Rights Campaign Foundation, 'LGBTQ Supplier Diversity Programs', https://www.thehrcfoundatio n.org/professional-resources/lgbtq-supplier-diversity-programs (accessed 31 October 2020); see also Unilever, ‘Supplier Diversity', https://www.unilever.com/suppliers/supplier-diversity/ (accessed 7 May 2021).
} 
- Peer support: Businesses may convene to discuss best practices and extend support to LGBTI-led businesses or LGBTI business leaders. ${ }^{49}$

- Marketing: Advertising campaigns can be powerful tools for countering harmful stereotypes and stigma. Businesses may opt to incorporate pro-LGBTI images, messages and targeting into their marketing. ${ }^{50}$

- Civil society support: Businesses may provide financial or in-kind support for civil society organizations and direct service providers. Corporate support for Pride celebrations and other efforts is frequently sought..$^{51}$

- Public policy: Finally, businesses may use their influence with a specific aim to influence public policy. This includes participation in litigation, ${ }^{52}$ decisions about where to expand, ${ }^{53}$ and issuing public positions on pro-LGBTI legislative proposals. ${ }^{54}$

\section{LGBTI Equality and Rights in Corporate Social Responsibility and Human Rights Frameworks}

The Standards were drafted to integrate both the human rights and broader CSR frames. A main thrust of CSR is its emphasis on the 'business case' - the argument that ethical corporate actions are ultimately good for business. ${ }^{55}$ On the other hand, the human rights approach is tied to the protection and realization of inalienable rights codified in the international human rights legal framework. ${ }^{56}$ These frameworks have long been understood as separate and, in many ways, oppositional, although recently there have been efforts to integrate these approaches. ${ }^{57}$

The Standards seek to merge the human rights and CSR strands. Because it informs a proper understanding of the Standards, the sections below consider how these disparate movements have taken up the intersections between business and the human rights of LGBTI people. Notably, the SOGIESC international human rights agenda and the BHR field have evolved largely independently, so these are addressed separately.

\section{SOGIESC and the Human Rights Agenda}

Despite increasing specification of human rights for particular groups, SOGIESC has not been explicitly recognized in international human rights treaties, with only a few recent

\footnotetext{
${ }^{49}$ For example, National LGBT Chamber of Commerce, 'What We Do', https://nglcc.org/what-we-do (accessed 7 May 2021); Pride Connection Chile, 'Objetivos', https://www.prideconnection.cl/\#objetivos (accessed 7 May 2021).

${ }^{50}$ Ana-Isabel Nölke, 'Making Diversity Conform? An Intersectional, Longitudinal Analysis of LGBT-Specific Mainstream Media Advertisements' (2018) 65:2 Journal of Homosexuality 224, 227; but see ibid 247 ('Despite positive developments ... [in] LGBT-specific mainstream ads, the intersectional analysis highlights the invisibility of the majority of identities within the queer spectrum.'). See also Bell, note 42, 139.

51 Todd Sears, 'The Human Power of Corporate Pride', Forbes (28 June 2019), https://www.forbes.com/sites/ toddgsears/2019/06/28/the-human-power-of-corporate-pride/?sh=47162d8f78a0 (accessed 31 October 2020).

${ }^{52}$ For example, Viet Tran, 'HRC Files Amicus Brief with Major Companies Supporting Transgender Students in Critical Case', Human Rights Campaign (28 February 2019), https://www.hrc.org/news/hrc-files-amicus-brief-withmajor-companies-supporting-trans-students (accessed 31 October 2020).

${ }^{53} \mathrm{CNBC}$, note 43.

54 See Caroline Kaeb, 'Corporate Engagement with Public Policy: The New Frontier of Ethical Business' (2018) 50:1 Case Western Reserve Journal of International Law 165.

55 This can be seen, for example, in the 'Business and Economic Case' section of the Standards, note 4, 18.

${ }^{56}$ Stéphanie Bijlmakers, Corporate Social Responsibility, Human Rights, and the Law (New York: Routledge, 2019$) 26$.

57 See Florian Wettstein, 'CSR and the Debate on Business and Human Rights: Bridging the Great Divide' (2012) 22:4 Business Ethics Quarterly 739, 748, 750; Anita Ramasastry, 'Corporate Social Responsibility Versus Business and Human Rights: Bridging the Gap Between Responsibility and Accountability’ (2015) 14:2 Journal of Human Rights 237, 238.
} 
exceptions. ${ }^{58}$ Likewise, compared with dramatic advances in LGBTI rights protections in numerous domestic legal frameworks, the protection of LGBTI people under international law has been slow and contested. ${ }^{59}$

Nonetheless, starting in 1994, UN treaty bodies have extended interpretations of human rights treaty protections to reach LGBTI people, starting with sexual orientation. ${ }^{60}$ Since the Human Rights Council's first SOGI resolution in June 2011, the Council has increasingly recognized and advanced the rights of LGBTI people, ${ }^{61}$ including through the creation of the Independent Expert on SOGI-based violence and discrimination. ${ }^{62}$ Other special procedures, ${ }^{63}$ regional bodies, ${ }^{64} \mathrm{UN}$ agency publications ${ }^{65}$ and civil society advocates have advanced the LGBTI human rights agenda.

This growing body of work has acknowledged the role of private actors but has, unsurprisingly, focused almost exclusively on state obligations to protect and guarantee access to justice. ${ }^{66}$ There has been no reference or clear interaction of this agenda with BHR frameworks. The Independent Expert has looked to the state duty to regulate private actors in thematic reports on economic and social marginalization and the practices of conversion 'therapy', as well as in specific country visits. ${ }^{67}$ In terms of directly addressing private actors, the Independent Expert has emphasized: 'Anti-rights narratives must be countered forcefully by political, religious and traditional leaders, by business sectors and by the media. ${ }^{68}$

The Yogyakarta Principles are an important piece of this human rights trajectory. ${ }^{69}$ Drafted by a renowned group of civil society experts in 2006 and revised in 2017, the Principles are a non-binding but authoritative restatement of how international human

\footnotetext{
${ }^{58}$ For example, Council of Europe Convention on Preventing and Combating Violence against Women and Domestic Violence, CETS No. 10 (adopted on 11 May 2011, entered into force on 1 August 2014), art 4(3); Inter-American Convention against All Forms of Discrimination and Intolerance, A-69 (adopted on 5 June 2013, entered into force on 20 February 2020), pmbl art 1; Inter-American Convention on Protecting the Human Rights of Older Persons, A-70 (adopted on 15 May 2015, entered into force on 11 January 2017), arts 5, 9.

${ }^{59}$ Rafael Carrano Lelis and Gabriel Coutinho Galil, 'Direito Internacional Monocromático: Previsão e Aplicação dos Direitos LGBTI na Ordem Internacional' (2018) 15:1 Revista de Direito Internacional 175, 175.

${ }^{60}$ Toonen v Australia Communication No. 488/1992, UN Doc CCPR/C/50/D/488/1992 (1994).

${ }^{61}$ Human Rights Council, 'Protection Against Violence and Discrimination Based on Sexual Orientation and Gender Identity', A/HRC/RES/32/2 (30 June 2016); Human Rights Council, 'Human Rights, Sexual Orientation and Gender Identity', A/HRC/RES/27/32 (2 October 2014).

${ }^{62}$ Human Rights Council (2016), note 61, para 3.

${ }^{63}$ For example, Human Rights Council, 'Report of the Special Rapporteur on the Right to Privacy', A/HRC/43/52 (12 February 2020).

${ }^{64}$ The inter-American system led by adopting a thematic focus on the rights of LGBTI persons in 2011 and creating a Rapporteurship in 2014. See generally IACHR, 'Recognition of the Rights of LGBTI Rights', OEA/Ser.L/V/ II.170 (7 December 2018).

65 office of the High Commissioner for Human Rights, note 2.

${ }^{66}$ At the time of writing OHCHR is developing a guide for civil society advocates on how to engage with private actors to advance the rights of LGBTI persons.

${ }^{67}$ For example, Human Rights Council, 'Visit to Georgia: Report of the Independent Expert on Protection Against Violence and Discrimination Based on Sexual Orientation and Gender Identity', A/HRC/41/45/add.1 (15 May 2019), paras 65,78 .

${ }^{68}$ UN General Assembly, note 16, para 35.

${ }^{69}$ Second International Panel of Experts in International Human Rights Law, Sexual Orientation, Gender Identity, Gender Expression and Sex Characteristics, 'Yogyakarta Principles Plus 10' (2017), http://yogyakartaprin ciples.org/wp-content/uploads/2017/11/A5_yogyakartaWEB-2.pdf (accessed 27 August 2021); International Panel of Experts in International Human Rights Law, Sexual Orientation, Gender Identity, Gender Expression and Sex Characteristics, 'Yogyakarta Principles' (2007), https://www.refworld.org/pdfid/48244e602.pdf (accessed 2 August 2021).
} 
rights norms apply to SOGIESC. These focus on state obligations, including the obligations to prevent and remedy abuses committed by private actors, namely in the Principles on equality and non-discrimination, accountability, education, sanitation, work, health, detention facilities, and the right of protection from poverty. The annex to the Yogyakarta Principles calls on businesses to 'act upon the important role they have in both ensuring respect for these Principles with regard to their own workforces and in promoting these Principles nationally and internationally'. ${ }^{70}$

\section{SOGIESC and the BHR Field}

Besides the Standards, the BHR field has not yet engaged substantively with SOGIESC. In the only academic discussion to consider the SOGIESC dimensions of BHR frameworks, Galil, Lelis and Angelucci review several key BHR documents for any reference to LGBTI persons or SOGIESC. ${ }^{71}$ They conclude that 'generally, the human rights and business agenda has contributed little to advance the protection of LGBTI rights, especially when compared to the great potential for action'. ${ }^{72}$

Although the UNWG has not taken up SOGIESC as an explicit focus, it has recognized the need for specialized attention to sexual orientation and gender identity. ${ }^{73}$ The UNWG has acknowledged the differential experience of the LGBTI community during its country visits $^{74}$ and mentioned the Standards on several occasions. ${ }^{75}$

The UNWG's 2019 Gender Guidance focused on women and girls and makes explicit that this includes transgender and intersex women. ${ }^{76}$ The Gender Guidance notes that it 'should be read together' with the Standards. ${ }^{77}$ In describing the Gender Guidance project, the UNWG notes that it 'seeks to support and complement broader efforts to combat gender discrimination, including discrimination based on sexual orientation and gender identity. ${ }^{78}$

In an important advance, the Inter-American Commission on Human Rights (IACHR) includes a dedicated section on the rights of LGBTI persons in its 2019 report on BHR. ${ }^{79}$ It covers discrimination and violence at work, cites the Standards ${ }^{80}$ and emphasizes that businesses play an essential role in changing stereotypes. ${ }^{81}$

\footnotetext{
${ }^{70}$ International Panel of Experts in International Human Rights Law, Sexual Orientation, Gender Identity, Gender Expression and Sex Characteristics (2007), note 69, 33.

${ }^{71}$ Galil, Lelis and Angelucci, note 5.

72 Ibid, 191. Unofficial translation from the original Portuguese.

${ }^{73}$ UN General Assembly, 'Human Rights and Transnational Corporations and Other Business Enterprises', A/72/162 (18 July 2017), para 11.

${ }^{74}$ Human Rights Council, 'Visit to Thailand: Report of the Working Group on the Issue of Human Rights and Transnational Corporations and Other Business Enterprises', A/HRC/41/43/Add.1 (21 May 2019), para 67; Human Rights Council, 'Report of the Working Group on the Issue of Human Rights and Transnational Corporations and Other Business Enterprises on its Mission to Peru', A/HRC/38/48/Add.2 (9 May 2018), para 59.

${ }^{75}$ Human Rights Council, 'Visit to Georgia: Report of the Working Group on the Issue of Human Rights and Transnational Corporations and Other Business Enterprises', A/HRC/44/43/Add.1 (24 April 2020), para 77; General Assembly, 'Visit to Kenya: Report of the Working Group on the Issue of Human Rights and Transnational Corporations and Other Business Enterprises', A/HRC/41/43/Add.2 (21 May 2019), para 695.

${ }^{76}$ Gender Guidance, note 21, 46. The Working Group has observed that 'the impact of business-related abuses is experienced by men, women and non-binary persons differently'. Human Rights Council (2020), note 75, para 71.

77 Gender Guidance, note 21, 49.

78 Office of the High Commissioner for Human Rights, 'Gender Lens to the UNGPs', https://www.ohchr.org/EN/ Issues/Business/Pages/GenderLens.aspx (accessed 31 October 2020).

${ }^{79}$ Muñoz, note 41, paras 379-89.

${ }^{80}$ Ibid, para 385.

${ }^{81}$ Ibid, para 386.
} 
Although there is increasing recognition of the need to incorporate a SOGIESC lens into BHR work, there is a risk that simple references to the Standards actually obscure the remaining gaps in terms of fully integrating SOGIESC into BHR frameworks.

\section{CSR Engagement with LGBTI Equality and Inclusion}

In contrast to the reticence in the human rights framework to engage with SOGIESC, there is an extensive history of private sector engagement on LGBTI equality and inclusion, primarily in the United States (US) and Europe, from a D\&I, public relations/marketing, and general CSR approach. This includes, inter alia, national corporate benchmarking initiatives, ${ }^{82}$ private sector associations at the national and regional level, ${ }^{83}$ and industryspecific efforts. ${ }^{84}$ US businesses have long been targets of LGBTI grassroots advocacy, and this relationship eventually evolved into business advocacy on LGBTI issues. ${ }^{85}$

Since 2015 initiatives related to the role of business in advancing LGBTI equality and inclusion have proliferated at the global level in fora and processes that are to varying degrees disconnected from the international human rights framework: ${ }^{86}$ namely, corporate-led efforts tied to the UN Global Compact, ${ }^{87}$ the World Economic Forum ${ }^{88}$ and the Sustainable Development Goals. ${ }^{89}$ This also coincides with the increased internationalization of prominent national-level LGBTI CSR initiatives, such as the US-based Human Rights Campaign $^{90}$ and the UK-based Stonewall International. ${ }^{91}$

The Standards seek to merge the CSR and human rights strands, but are a direct result of this particular line of developments. In 2016 the World Economic Forum agenda in Davos included consideration of LGBTI issues for the first time. UN High Commissioner for Human Rights, Zeid Ra'ad Al Hussein, participated in a panel event there and has stated that this discussion spurred the idea of developing the Standards. ${ }^{92}$ OHCHR, led by staff in New York with support from the Institute for Human Rights and Business, developed the Standards over the following year and published them in September 2017.93

\footnotetext{
${ }^{82}$ For example, Human Rights Campaign, 'Corporate Equality Index', https://www.hrc.org/resources/corpo rate-equality-index (accessed 7 May 2021).

${ }^{83}$ For example, National LGBT Chamber of Commerce, note 49.

${ }^{84}$ For example, International Gay and Lesbian Travel Association, 'Away We Went', https://www.iglta.org/ Portals/79/docs/Support\%20Docs/iglta-timeline.pdf?ver=2019-03-28-200327-967 (accessed 31 October 2020).

${ }^{85}$ Bell, note $42,1-7$.

${ }^{86}$ As is described further below, the protagonists of this movement are almost exclusively global businesses headquartered in the Global North.

${ }^{87}$ UN Global Compact, 'The Role of Business in Equality and Human Rights for the LGBT Community', https:// www.unglobalcompact.org/library/1211 (accessed 31 October 2020).

${ }^{88}$ Partnership for Global LGBTI Equality, 'Who We Are', https://www.global-lgbti.org/who-we-are (accessed 31 October 2020).

${ }^{89}$ Felicity Daly, 'LGBT+Inclusion and the UN Sustainable Development Goals' (2020), https://static1.squarespace. com/static/5bba53a8ab1a62771504d1dd/t/5f6b4f3a978b0513584d2280/1600868211690/SDG-LGBT+inclusion.pdf (accessed 27 August 2021).

90 The US-based Human Rights Campaign created its Global Business Coalition in 2015. See Human Rights Campaign, ‘Global Business Coalition', https://www.hrc.org/resources/global-business-coalition (accessed 31 October 2020).

91 The UK-based Stonewall International launched its Global Workplace Equality Index in 2017. See Stonewall, 'Global Workplace Equality Index', https://www.stonewall.org.uk/global-workplace-equality-index (accessed 31 October 2020).

92 The origins of the Standards are explained in the High Commissioner's preface to the Standards document. The Standards, note $4,1$.

93 Ibid.
} 
In terms of how the CSR strand has engaged with LGBTI issues, one particularly influential framing - cited in the Standards - of how global business can engage with LGBTI inclusion across legal and cultural environments describes three models of action: ${ }^{4}$ (1) where companies abandon their non-discrimination policies in inhospitable political and legal environments (When in Rome model); (2) where they create a welcoming workplace in a hostile national environment without challenging that environment (Embassy model); or (3) where they actively try to change anti-LGBTI laws and social attitudes wherever they operate (Advocate model). ${ }^{95}$ For proponents of these models, companies would ideally 'adjust their policies and initiatives to local laws and cultural norms' and 'spin up' to stronger positions on LGBTI rights over time. ${ }^{96}$

Across LGBTI movements, there is no unified view or assessment of the increased protagonism of global business as champions for LGBTI inclusion. Many LGBTI organizations - particularly those participating in international agenda-setting but also many of those seeking to advance their agendas at the local and national levels - take an approach to private sector engagement that seeks incremental change by improving and leveraging existing frameworks and processes. For critical scholars and activists, however, CSR broadly (whether in human rights terms or not) is largely seen as a vehicle to reify neo-colonialism through private sector power hierarchies..$^{97}$ This is especially pronounced in the flashpoint issue of LGBTI rights. LGBTI advocates - typically those identifying with critical 'queer' scholarship, activism and movements, as well as those expressing solidarity with or co-membership in other critical movements - have accused companies of co-opting the LGBTI movement for profit through empty virtue-signalling. ${ }^{8}$ Their foundational concern is that queer liberation is incompatible with capitalism and homonormativity. ${ }^{99}$ Queer liberation movements and approaches emphasize solidarity with broader struggles against imperialism, capitalism and consumerism - causes that do not typically see allyship in global business. ${ }^{100}$ Mirroring the postcolonial critiques of CSR espoused by feminist scholars and other CSR sceptics, ${ }^{101}$ these critics argue that offering businesses the label of 'socially responsible' obscures these contradictions and frustrate efforts for real transformation by placating individuals and groups who would otherwise be demanding systemic change. ${ }^{102}$

\section{The UN Standards of Conduct for Business}

As described above, the Standards, an OHCHR initiative, emerged as part of a wave of corporate-led initiatives and discussions on the role of global business in championing LGBTI equality. ${ }^{103}$ The development of the Standards was arguably speedy compared with other UN publications and processes; the idea was first spurred by the January 2016 World Economic Forum meeting in Davos and OHCHR launched the official Standards publication

\footnotetext{
${ }^{94}$ David Glasgow and Kenji Yoshino, Opening Up the World: How Multinational Organizations Can Ascend the Maturity Curve on LGBT+ Rights (New York: NYU School of Law \& Center for Diversity, Inclusion, and Belonging, 2020) 5-10.

${ }^{95}$ Ibid, 11-7.

${ }^{96}$ Ibid, 2.

97 Bijlmakers, note 56, 30; Ozkazanc-Pan, note 22.

98 See Bell, note 42, 204-207.

${ }^{99}$ See Adler, note 14, 164-165; Cameron McKenzie, 'Queer Liberation Theory: A Genealogy', Oxford Research Encyclopedia of Politics (2020).

100 See McKenzie, note 99.

${ }^{101}$ See Ozkazanc-Pan, note 22; McKenzie, note 99.

102 Timothy Kuhn and Stanley Deetz, 'Critical Theory and Corporate Social Responsibility: Can/Should We Get Beyond Cynical Reasoning?' in Andrew Crane et al (eds.), Oxford Handbook of Corporate Social Responsibility (Oxford University Press: Oxford, 2008) 175.

103 See Section III.
} 
in September 2017. The drafting process for the Standards counted on a series of regional consultations with business leaders, academics and members of civil society.

This section analyses the design of the Standards, which integrates elements from the CSR and human rights strands and which is consistent with the main human rights principles espoused in Pillar 2 of the UNGPs. We then survey dimensions of the uptake that raise concerns about the predominance of a more ambiguous and diffuse CSR approach.

\section{The Standards as Designed: Strong Human Rights Orientation}

The Standards are explicitly grounded in existing international human rights law and the UNGPs, and they concisely spell out a wide range of human rights norms and principles, clearly linking the Standards to UNGPs Pillar 2. The Standards speak in terms of both 'responsibilities' and 'opportunities'. As then High Commissioner Zeid Ra'ad Al Hussein announced: 'If we are to achieve faster global progress towards equality for lesbian, gay, bi, trans, and intersex people, businesses will not only have to meet their human rights responsibilities, they must become active agents of change. ${ }^{104}$

The document sets out five standards:

(1) Respect Human Rights;

(2) Eliminate Discrimination in the Workplace;

(3) Provide Support in the Workplace;

(4) Prevent Other Human Rights Violations in the Marketplace; and

(5) Act in the Public Sphere.

Standard 1 (to respect human rights) matches UN Guiding Principle 11. The commentary reiterates that all businesses have a responsibility to respect the human rights of LGBTI people at all times and that this responsibility exists independently of the state; it also lays out Pillar 2 expectations related to company policy, due diligence, remedy, and monitoring and communication.

Standards 2 and 3 both relate to the workplace. Standard 2 calls on companies to eliminate discrimination in 'recruitment, employment, working conditions, benefits, respect for privacy, or treatment of harassment." ${ }^{105}$ Although not referenced in the publication, existing human rights standards and ILO norms offer extensive guidance for gauging this Standard. ${ }^{106}$ Standard 3 on the other hand, to provide support in the workplace, is more ambiguous and an insertion from the CSR field's focus on voluntary measures. The document offers little analysis of this standard compared with the others and has only a short paragraph urging support for the 'informal staff groups' or employee resource/ affinity groups that have become a staple of inclusive corporate culture. ${ }^{107}$

Standard 4 speaks to preventing human rights violations in the 'marketplace' and considers discrimination against LGBTI suppliers, distributors or customers alongside the actions of business partners. Discrimination and violence in the private provision of essential services such as education and health are included as 'in the marketplace' but given special emphasis. The publication highlights explicitly patterns of violence, torture and ill-treatment against LGBTI people in schools, health care facilities, detention centres, and in the context of law enforcement or security operations, as well as incitement to hatred and violence in the media sector. It also sets out the proactive opportunity for the private

\footnotetext{
${ }^{104}$ The Standards, note 4, preface.

105 Ibid, 5.

${ }^{106}$ For example, International Labour Office, Equality at Work: The Continuing Challenge (Geneva: ILO, 2011).

107 The Standards, note 4, 11.
} 
sector to 'actively support partners and suppliers who extend opportunities, products and services on a non-discriminatory basis to LGBTI people and those who recruit them' ${ }^{108}$

Finally, Standard 5 calls on businesses to act in the public sphere. This standard has raised the most questions in terms of meaning and application. ${ }^{109}$ From a human rights perspective, Standard 5 can be read consistently with the UNWG's Gender Guidance and current understanding of UNGP 11 that it includes an affirmative responsibility to take measures to advance substantive gender equality. ${ }^{110}$

The Standards have strong human rights underpinnings that scholars and advocates can leverage to make the link between existing research and policy work related to broader business and human rights frameworks, the overall international human rights system, and more robust consideration of SOGIESC dimensions. As described below, this link has not been actualized in scholarship or practice.

\section{Endorsement of the Standards: Both Systemic and Idiosyncratic}

Immediately after publishing the Standards in 2017, OHCHR began encouraging the world's multinational corporations to express their support for the document, described further below. As of October 2020, 304 companies have expressed support for the Standards and are included in the official list of 'Supporters'. ${ }^{111}$ This number pales in comparison with the Women's Empowerment Principles (3,811 companies) ${ }^{112}$ and the UN Global Compact $(15,804$ participants). ${ }^{113}$ However, although the Standards' roster is small, it is mighty. It features many of the world's largest businesses: 80 of the 304 Supporters appear on Fortune's 2020 Global 500;114 158 Supporters are publicly traded; and the companies listed as Supporters own 44 of the Top 100 most valuable brands present on the Forbes 2020 Brand Value list. ${ }^{115}$

The vast majority of the Supporters (83 per cent) are headquartered in the Global North (Europe, US/Canada, Australia, Japan, Israel). Europe-based companies account for 136 (45 per cent) of the 304 Supporters, and 102 (34 per cent) are based in the US. The third most-represented nation after the US and the United Kingdom (UK) is Brazil, which is the headquarters for 27 Supporters. A total of 48 Supporters (16 per cent) are headquartered in the Global South. The remaining 1 per cent represents companies with multiple or unknown headquarters. Only one Supporter, an IBM subsidiary, has its sole headquarters in Africa, although a couple of others, such as Anglo-American plc and Palladium Group, have major corporate footprints on the continent.

As is shown in Table I, in terms of industry representation, one third of the Supporters hail from the banking and financial services, legal or consulting sectors. ${ }^{116}$ Companies from the

\footnotetext{
108 Ibid.

${ }^{109}$ Drew Keller et al, 'Channels of Influence: How Companies Can Promote LGBT+ Inclusive Societies' (2015), http://www.sistersforchange.org.uk/wp-content/uploads/2020/docs/01-SFC-DB-FILES/464-Channels-of-Influence_How-Companies-Can-Promote-LGBT-Inclusive-Societies.pdf (accesssed 27 August 2021).

110 Gender Guidance, note 21, 20-21; Human Rights Council, 'Guiding Principles on Business and Human Rights: Implementing the United Nations "Protect, Respect and Remedy” Framework', A/HRC/17/31 (21 March 2011) 13 (UNGPs).

111 Partnership for Global LGBTI Equality, note 10.

${ }^{112}$ Women's Empowerment Principles, ‘WEPs Signatories', https://www.weps.org/companies (accessed 31 October 2020).

${ }^{113}$ UN Global Compact, 'Our Participants', https://www.unglobalcompact.org/what-is-gc/participants (accessed 31 October 2020).

${ }^{114}$ Fortune, 'Global 500', https://fortune.com/global500/ (accessed 31 October 2020).

${ }^{115}$ Forbes, 'The World's Most Valuable Brands 2020', https://www.forbes.com/the-worlds-most-valuablebrands/\#76f05c24119c (accessed 31 October 2020).

${ }^{116}$ We have adopted the same industrial classification categories used by the Human Rights Campaign's 2020 Corporate Equality Index. Human Rights Campaign, 'Corporate Equality Index 2020', https://www.hrc.org/ resources/corporate-equality-index (accessed 31 October 2020).
} 
extractive, manufacturing, private security firms, agribusiness, utilities and construction industries are largely absent. ${ }^{117}$ In terms of education and health services, there is one hospital and one small university on the list.

Support for the Standards has been driven by both systemic and idiosyncratic forces. Supporters are concentrated in sectors with high-skilled workers and public-facing brands. Sectors that depend on a highly educated workforce face a market pressure to be openly LGBTI-friendly, as D\&I is increasingly important for competitive recruitment. ${ }^{118}$ Industries highly sensitive to consumers (retail, apparel, food/beverage) face similar pressure and incentives to openly conform their brands with a pro-LGBTI image, at least in the locations where they are headquartered. ${ }^{119}$ Additionally, in interviews and in public statements by companies, spokespeople emphasized where they were the first in their industry to commit to the Standards, and in several cases, OHCHR could leverage high profile commercial rivalries to encourage companies to join their main competitors on the list of Supporters.

Some companies expressed support for the Standards in the wake of negative coverage about LGBTI discrimination. The Dorchester Collection, a hotel chain owned by the Brunei sovereign wealth fund, faced boycotts because of Brunei's draconian anti-LGBT laws ${ }^{120}$ and recently expressed its support for the Standards. ${ }^{121}$ Thai beauty company SSUP Group announced its support for the Standards soon after being accused of discriminating against a transgender job applicant. ${ }^{122}$

On the other hand, expressions of support for the Standards also reflect circumstantial factors and the dissemination strategy to date. UN Free and Equal had staff in-country in Brazil, which likely explains why Brazil so dramatically outpaces other countries in the Americas in support for the Standards. Brazil is home to 84 per cent of all Supporters based in Latin America and the Caribbean. One unique Supporter - a small yoga studio based in Dili, Timor-Leste - seems like a strange addition, but it teaches yoga classes in the UN compound in Dili.

There are several factors that keep otherwise interested and generally aligned companies from expressing support for the Standards. Our interviews suggest there is some exhaustion in terms of audits and benchmarks and a sense that the Standards are duplicative and less clear than existing corporate indices. As in other contexts, legal departments can be reluctant to see any benefit from expressing support and instead fear that increased endorsement of ambiguous standards and the related reporting could have implications in terms of liability in the future. Finally, there is particular hesitation around what is expected under Standard 5 to act in the public sphere. The approach from proponents of the Standards has generally been to emphasize the voluntary nature of the Standards and the margin of discretion for private sector actors to determine which actions, if any, are appropriate.

\footnotetext{
${ }^{117}$ Notable exceptions include Anglo-American, Monsanto, Royal Dutch Shell and Syngenta. Partnership for Global LGBTI Equality, note 10.

118 Shaun Pichler et al, 'Do LGBT-Supportive Corporate Policies Enhance Firm Performance?' (2018) 57:1 Human Resource Management 263, 274; Maks-Solomon and Drewry, note 46, 33-34, 143-44.

119 Bell, note 42, 32-33; Maks-Solomon and Drewry, note 46, 129, 148.

120 'Deutsche Bank Has Removed All Hotels Owned by the Sultanate of Brunei from its Supplier List', Deutsche Bank (4 April 2019), https://www.db.com/newsroom_news/2019/deutsche-bank-has-removed-hotels-owned-bythe-sultanate-of-brunei-from-its-supplier-list-en-11461.htm (accessed 31 October 2020).

${ }^{121}$ Partnership for Global LGBTI Equality, note 10.

122 'Tackling Gender Discrimination at the Workplace: The Case of June vs. Cute Press (SSUP Group)!', Manushya (31 August 2020), https://www.manushyafoundation.org/post/tackling-gender-discrimination-at-the-workplacethe-case-of-june-vs-cute-press-ssup-group (accessed 31 October 2020).
} 
Table I. Top 5 Sectors represented by Supporters of the Standards, as of October 2020

\begin{tabular}{llc}
\hline & Sector & Number of Supporters \\
\hline$(1)$ & Banking and financial services & 56 \\
\hline$(2)$ & Law firms & 26 \\
\hline$(3)$ & Consulting and business services & 23 \\
\hline$(4)$ & Retail and consumer products & 22 \\
\hline$(5)$ & Apparel, fashion, textiles, dept stores & 21 \\
\hline
\end{tabular}

\section{Roll-Out of the Standards: Untethered from Human Rights}

The most striking feature of the roll-out of the Standards has been a transfer of the 'ownership' of the initiative from OHCHR to the World Economic Forum's Partnership for Global LGBTI Equality (PGLE). PGLE was created in 2019 by a coalition of multinational corporations; it follows a buy-in model for businesses and is funded by contributions from the founding members. The work is supported by Business for Social Responsibility (BSR) and directed by a steering committee. As of October 2020, 17 of the 21 members of PGLE's steering committee come from the business sector, including nine D\&I executives. ${ }^{123}$ The remaining spots on the steering committee are representatives from OHCHR, the World Economic Forum, OutRight International and Human Rights Watch. ${ }^{124}$ The PGLE was created with several aims, including a specific mandate to operationalize the Standards and increase the number of endorsements. ${ }^{125}$

Following the launch of the Standards by OHCHR in 2017, the UN Free and Equal Campaign was responsible for their global dissemination, and OHCHR kept and managed the list of Supporters, which was not published anywhere. ${ }^{126}$ In 2020, the PGLE assumed responsibility for managing the inclusion of companies on the official list of Supporters, and the list of Supporters was made public on the PGLE website. OHCHR's website directs businesses that wish to formalize their support for the Standards to do so through the PGLE website. ${ }^{127}$ The PGLE website instructs businesses to express their support for the Standards via a letter from a senior executive addressed to OHCHR and uploaded on the PGLE site. The page notes clearly that "[s]upport for the Standards shall not impose on the supporting company any duties or obligations related to compliance with the Standards. ${ }^{128}$

In fact, the 'ownership' of the Standards was never primarily within the human rights framework or community. Although the Standards were crafted under the auspices of $\mathrm{OHCHR}$, and with the expert support of the Institute for Human Rights and Business, the impetus for the Standards and the consultative input into their design came from global corporate leadership fora. ${ }^{129}$ As described above in Section II, the idea for the Standards

\footnotetext{
${ }^{123}$ Partnership for Global LGBTI Equality, 'Steering Committee', https://www.global-lgbti.org/steering-commit tee (accessed 31 October 2020).

${ }^{124}$ Ibid.

125 'Global Businesses Unite, Launching Partnership for LGBTI Equality in the Workplace', World Economic Forum (9 May 2019), https://www.weforum.org/our-impact/LGBTI-equality-in-workplace (accessed 31 October 2020).

${ }^{126}$ UN Free and Equal, 'Standards of Conduct for Business', https://www.unfe.org/standards/ (archived 7 March 2018 at https://web.archive.org/web/20180307054740/https://www.unfe.org/standards/).

${ }^{127}$ Partnership for Global LGBTI Equality, 'Become a Supporter', https://www.global-lgbti.org/become-a-sup porter (accessed 31 October 2020).

128 Ibid.

129 The Standards, note 4, 1.
} 
emerged out of a session at the World Economic Forum's annual meeting in Davos during a wave of interest in the role of multinational corporations in advancing LGBTI equality.

Additionally, the vast majority of knowledge production on the Standards to date has come from corporate membership organizations. In addition to the PGLE, other organizations actively engaging with the Standards include Involve, which has created guidance documents with 'top tips' on the Standards for its members, ${ }^{130}$ and Open for Business, which has produced several important reports related to the Standards, including one on Standard 5 titled 'Channels of Influence'. ${ }^{131}$ By comparison, the UN human rights system, BHR and LGBTI rights advocates, and academia have been largely silent in interpreting and leveraging the Standards. ${ }^{132}$

While more empirical research is needed to look into the many possible forms of internal and external monitoring and the business-level operationalization of the Standards, in general, companies seem to approach the Standards primarily as a D\&I opportunity. This observation stems from our own advocacy related to the Standards, and it is also reflected in how companies choose to publicize their endorsement of the Standards. More than 100 of the companies that are listed as supporters have produced public communications, i.e., press releases or webpages, highlighting their support for the Standards. In the majority of these communications, companies described the Standards in terms that emphasize workplace policies and culture, and in many instances, a company's support for the Standards is mentioned only on its D\&I or recruitment pages. Even where companies have human rights policies or actively engage with the UNGPs, most position their commitment to the Standards in the context of other CSR coalitions and multi-stakeholder platforms such as the Women's Empowerment Principles, the UN Global Compact, the Sustainable Development Goals, the HRC Global Business Coalition, and Open for Business, rather than as an outgrowth of the UNGPs. During our research, company leadership put forward to discuss the business's consideration of the Standards were often unfamiliar with the business's human rights policies, which were seen as addressing other issues. So far, it appears that the embedding of the Standards and/or SOGIESC into human rights policies and human rights reporting is weak. Of the 304 listed 'Supporters' of the Standards, 185 have publicly available human rights policies and/or human rights reports. Only 75 of those make any explicit reference to LGBTI or SOGI and almost all of those references are specific to nondiscrimination in the workplace.

As a positive example, one of the Standards' first supporters, SAP, a German software company, updated its Global Human Rights Commitment Statement to specifically mention LGBTI people, and the Statement references the Standards together with other international human rights standards, including the UNGPs. ${ }^{133}$ Microsoft, a member of the PGLE Steering Committee and identified leader in this space, has also produced a comprehensive human rights policy that makes extensive commitments across all areas of its business and references SOGIESC throughout; notably, Microsoft contextualizes the Standards alongside its commitments to UN human rights treaties, not voluntary, multistakeholder CSR initiatives. ${ }^{134}$

\footnotetext{
${ }^{130}$ Involve, 'UN LGBTI Standards of Conduct', https://www.involvepeople.org/page/UNLGBTIStandardsofCon duct (accessed 31 October 2020).

${ }^{131}$ Keller et al, note 109.

${ }^{132}$ At the time of writing, we are anticipating the release of a guide on engaging the private sector to advance LGBTI rights by OHCHR.

133 SAP, 'SAP Global Human Rights Commitment Statement', https://assets.cdn.sap.com/sapcom/docs/2016/ 01/a8c6d366-577c-0010-82c7-eda71af511fa.pdf (accessed 31 October 2020).

${ }^{134}$ Microsoft, 'Microsoft Global Human Rights', https://www.microsoft.com/en-us/corporate-responsibility/ human-rights-statement?activetab=pivot_1:primaryr8 (accessed 7 May 2021).
} 
Finally, a critical missing link in terms of a human rights approach versus a CSR approach is the lack of accountability mechanisms or benchmarks for evaluating implementation and progress. In terms of accountability, the Standards publication explains that: "While companies are encouraged to support, endorse, and refer to these Standards in reporting on their actions to respect and promote human rights, the Standards do not come with a mechanism to monitor their application'. ${ }^{135}$ OHCHR does not commit to engage in monitoring, but 'encourages companies themselves, as well as trade unions, civil society organizations, academic institutions, and other stakeholders to monitor and evaluate performance' and to use other benchmarking mechanisms. ${ }^{136}$

\section{Advancing a Robust, Human Rights-Based Approach to Business and LGBTI Equality}

The Standards are an important contribution for more robust research and advocacy into the SOGIESC dimensions of the human rights impacts, responsibilities and opportunities for business actors. For this potential to be realized, scholars, practitioners and advocates must reclaim the Standards' rights-based framing and further integrate SOGIESC into BHR frameworks. This section first considers why a robust rights-based approach to the Standards, and to LGBTI rights and business more broadly, is necessary and then proposes priority areas for future research and engagement.

\section{Considerations for Insisting on a Human Rights Framing}

First, a human rights framing is necessary to understand the content of the Standards as drafted. Understanding the Standards requires engagement with human rights standards and principles because the expectations and responsibilities described in each standard intentionally echo key debates, concepts and principles that have particular meanings in the BHR field. If the Standards are treated as an isolated initiative, untethered from the international human rights system, their actual guidance and expectations are unintelligible. For example, the standard of 'respect human rights' is ambiguous and unhelpful on its own, until linked with core human rights treaties and the clear Pillar 2 requirements related to company policy, due diligence and accountability measures. Especially in terms of the international LGBTI human rights agenda, the contours of rights and obligations have evolved from the advocacy grounded in the lived experiences of people around the world. Thus, the link to the human rights system (including International Labour Organization developments) imbues the Standards with meaning and provides relevant benchmarks for monitoring.

Second, the insistence on a rights and dignity framing as opposed to other paradigms is critical in the face of intense anti-LGBTI, anti-rights discourses and consistent attacks. Recent notable examples at the international level include the opposition against the renewal of the Independent Expert's mandate ${ }^{137}$ and the Trump administration's efforts to 're-dedicate' the Universal Declaration of Human Rights, ${ }^{138}$ stemming from the work of

\footnotetext{
135 The Standards, note 4, 13.

${ }^{136}$ Ibid.

${ }^{137}$ International Lesbian, Gay, Bisexual, Trans and Intersex Association, Compilation of the Adoption of the 2019 SOGI Resolution 41/18 (12 July 2019).

${ }^{138}$ Michael R Pompeo, 'Promoting and Protecting Human Rights: A Re-Dedication to the Universal Declaration of Human Rights', https://2017-2021.state.gov/promoting-and-protecting-human-rights-a-re-dedication-to-the-uni versal-declaration-of-human-rights/index.html (accessed 31 October 2020).
} 
the Commission on Unalienable Rights. ${ }^{139}$ Fabrice Houdart, Dan Bross and Salil Tripathi highlighted the importance of the rights frame in their introduction to the Standards in this journal: "the private sector has a limited understanding of this issue [LGBTI discrimination] and often sees it as pertaining to the worlds of "corporate culture", "tradition" or "private life" rather than human rights. ${ }^{140}$

Diverse LGBTI movements have adopted and emphasized the language and framing of human rights as a mobilization and advocacy strategy, although not necessarily linked to the international human rights system. The human rights frame is inseparable from notions of accountability; it emphasizes the dignity and agency of each person and is intentionally empowering.' ${ }^{\text {em1 }}$

Finally, reclaiming the human rights-based approach is a discursive and practical strategy to defend civil society space and core principles of accountability, transparency, participation, rule of law and equality in a context of increasing and unchecked corporate influence in local, national and global policy agendas. The intensifying attention of multinational corporations to LGBTI equality at the global and multilateral level is taking place in a broader context of private sector protagonism in UN agendas, which has been framed as 'philanthrolateralism', ${ }^{142}$ 'corporate capture', ${ }^{143}$ and most frequently 'partnership'. ${ }^{144}$ The nature of increased corporate engagement in global gender empowerment goals has received important scholarly attention. ${ }^{145}$ The concerns raised over corporate capture include the erosion of multilateral spaces, the lack of democratic access to participation and influence for human rights defenders, the cost-benefit orientation of business over the human rights system's emphasis on inalienability and universality, and the entrenchment of predatory economic development models. Prominent in these concerns is the ascendancy of the World Economic Forum, ${ }^{146}$ - the self-proclaimed International Organization for Public-Private Cooperation.

While not without exception, global multi-stakeholder platforms are generally less accessible to meaningful, diverse civil society participation than established UN human rights mechanisms. Engagement in international human rights mechanisms has been an important and powerful mobilizing tool for the LGBTI rights movement, catalysing links between elite international LGBTI organizations and smaller, otherwise unconnected grassroots LGBTI organizations. Notwithstanding shortcomings, the undermining of formal

\footnotetext{
${ }^{139}$ US Department of State, 'Report of the Commission on Unalienable Rights (2020), https://www.state.gov/wpcontent/uploads/2020/08/Report-of-the-Commission-on-Unalienable-Rights.pdf (accessed 31 October 2020).

${ }^{140}$ Bross, Houdart and Tripathi, note 5, 272.

${ }^{141}$ General Assembly, 'Report of the Special Rapporteur on Extreme Poverty and Human Rights', A/70/274* (4 August 2015), para 65.

${ }^{142}$ Karolin Seitz and Jens Martens, 'Philanthrolateralism: Private Funding and Corporate Influence in the United Nations' (2017) 8:S5 Global Policy 46.

${ }^{143}$ For example, 'Hundreds of Civil Society Organizations Worldwide Denounce World Economic Forum's Takeover of the UN', FIAN International (26 September 2019), https://www.fian.org/en/press-release/article/ hundreds-of-civil-society-organizations-worldwide-denounce-world-economic-forums-takeover-of-the-un-2207 (accessed 31 October 2020).

${ }^{144}$ World Economic Forum, 'The United Nations-World Economic Forum Strategic Partnership Framework for the 2030 Agenda', https://weforum.ent.box.com/s/rdlgipawkjxi2vdaidw8npbtyach2qbt (accessed 7 May 2021).

${ }^{145}$ Catia Gregoratti, 'Feminist Perspectives on the UN Women's Empowerment Principles' in Andreas Nölke and Christian May (eds.), Handbook on the International Political Economy of Gender (Cheltenham: Edward Elgar, 2018) 211; Magdalena Bexell, 'Global Governance, Gains and Gender' (2012) 14:3 International Feminist Journal of Politics 389.

${ }^{146}$ World Economic Forum, note 144; 'UN Signs Deal with Davos that Threatens Democratic Principles', TNI (3 July 2019), https://www.tni.org/en/article/un-signs-deal-with-davos-that-threatens-democratic-principles (accessed 31 October 2020); Amanda Lyons, 'A Paradigm Shift for the Sustainable Development Goals? Human Rights and the Private Sector in the New Social Contract' in Morten Kjaerum, Martha F Davis and Amanda Lyons (eds.), COVID-19 and Human Rights (London: Routledge, 2021).
} 
multilateral human rights spaces will arguably have a disparate negative impact on those groups to which the system is dedicated to protecting - those most vulnerable to state abuse and neglect and those who cannot count on domestic legislative or judicial protection. The human rights system of norms and actors, built over decades of civil society advocacy, should not be supplanted without close scrutiny.

That said, it remains open for debate as to whether either the BHR or broader CSR frames possess the full liberatory potential to eliminate structural SOGIESC-based discrimination and violence. Powerful feminist and post-colonial critiques of CSR highlight this concern. As Banu Ozkazanc-Pan has written, CSR is an example of neocolonial "rights" discourse: CSR imbues the specter of rights on its gendered subaltern subjects without affording agency, thereby (re) constructing neocolonial relations in the context of globalized neoliberalism and capitalism. ${ }^{147}$ This insight is particularly salient because it mirrors postcolonial or queer critique of the international LGBTI rights movement; the transnational 'gay' or 'LGBTI' rights discourse has been similarly criticized for imposing Euro-US identity categories upon indigenous sexual desires and gender epistemologies, ${ }^{148}$ prioritizing the goals and politics of LGBTI people in the Global North, ${ }^{149}$ and reifying neo-colonial hierarchies. ${ }^{150}$ The Standards are especially vulnerable to these critiques given their implicit focus on practices of businesses headquartered in the Global North, and the concentration of attention and buy-in from European and North American multinational businesses and transnational LGBTI civil society. While this article does not have space to fully analyse the Standards through these critical lenses, we hope to motivate future scholarship on the intersection between SOGIESC, human rights, business and critical theory, with a particular eye to whether engagement with instruments such as the Standards can ever be done in ways that evade and subvert the neo-colonial hierarchies which often define CSR and North-centric rights discourses.

\section{Priorities for Advancing a Rights-Based Approach}

We argue that, given their strong human rights underpinnings, the Standards can be a useful starting point for advancing deeper engagement at the nexus of business, human rights and SOGIESC. Researchers should build on the important intellectual contribution of the Standards and leverage their momentum among prominent multinational corporations to expand the consideration of SOGIESC dimensions into all BHR accountability work.

To this end, we suggest several priority areas for further research and attention by scholars, practitioners and advocates in order to advance a more robust, rights-based approach to the Standards and a fuller engagement with SOGIESC throughout the broader BHR framework.

First, more attention is needed in scholarship and practice at the nexus of LGBTI persons, human rights and business to the human rights challenges faced by the most marginalized. This more expansive scope of human rights challenges is generally not captured by a vague reference to 'LGBTI issues' or even 'LGBTI equality' when conceived only as formal and not substantive equality. It follows that LGBTI equality efforts, if they are to be pursued in terms

\footnotetext{
${ }^{147}$ Ozkazanc-Pan, note 22, 857.

148 Joseph Andoni Massad, 'Re-Orienting Desire: The Gay International and the Arab World' (2002) 14:2 Public Culture 361, 383-85.

149 Seckinelgin, note 24, 286; Brenna Munro and Gema Pérez-Sánchez, 'Introduction: Thinking Queer Activism Transnationally', Scholar \& Feminist Online (2017), http://sfonline.barnard.edu/thinking-queer-activism-transna tionally/introduction-thinking-queer-activism-transnationally/0/ (accessed 19 April 2021).

150 See Stewart Chang, 'The Postcolonial Problem for Global Gay Rights' (2014) 32:2 Boston University Journal of International Law 309, 312-17.
} 
of human rights, cannot be separated from other human rights priorities such as addressing violence, poverty, racism, imperialism, environmental injustice, workers' rights violations, conflict, displacement, corruption, tax justice and gender inequality.

In certain contexts, and especially for large businesses headquartered in the US and Europe, adoption of LGBTI inclusion as a company's banner human rights commitment is relatively low cost, does not imply any adjustment to business operations, and is in line with pre-existing business objectives. Generic commitments to LGBTI workplace culture can be a low-hanging fruit compared with other human rights concerns which would require substantive adjustments to the business model. ${ }^{151}$ Because a globalized 'LGBTI identity' is often de-linked from gender, racial, colonial or class contexts, ${ }^{152}$ businesses may profess broad support for 'LGBTI issues' without being required to consider their role or relationship to structural forces that harm particularly vulnerable LGBTI people. Allyship with LGBTI persons, if framed as a human rights commitment, must be translated into robust and comprehensive human rights policies and procedures that count on the meaningful, ongoing participation by rights-holders - in the design, implementation and review of policies and initiatives.

An example from the Standards helps illustrate that discrimination, and the required responses, have different manifestations across a company or a community. Among the 'case studies' in the Standards publication are examples of companies' 'ad-hoc solutions to discriminatory legislation', including for employees who are sent abroad to work. The examples include a company that covers an employee's rent and cleaning fees for a two-bedroom apartment to maintain the appearance that same-sex partners are living in separate rooms, and a company that offers an employee posted abroad who is not able to bring their same-sex partner abroad additional leave to return home and maintain the familial relationship. ${ }^{153}$ While these are important measures to ensure LGBTI inclusion at an upper level of a multinational company, these experiences or responses are not relevant to the most prevalent human rights challenges faced on the basis of SOGIESC in the context of business. Scholarship and practical engagement with the Standards must avoid using the white-collar LGBTI employees as the sole template by which success is measured.

To address these limitations and biases, more attention is needed to explore what an intersectional and non-binary approach to sex and gender would entail in the BHR field.

Second, another critical gap where attention is needed is on the SOGIESC dimensions of the state duties to protect and to guarantee access to remedy. National and international considerations of the state duties to protect and to guarantee access to remedy in BHR frameworks, including in National Action Plans, have not incorporated a cross-cutting consideration of the differential and disparate harms based on SOGIESC. ${ }^{154}$ This question is completely untouched by the development of the Standards, which by definition focuses only on the corporate responsibility to respect, which exists independent of state human rights duties. Despite this limited focus, the Standards have been largely treated as having fulfilled the pending task of considering the SOGIESC dimensions of BHR.

The failure of states around the world to protect the rights of LGBTI persons is frequently hailed to justify and mobilize the increased protagonism by multinational business leaders. However, from a human rights perspective, the state remains a critical site for advancing the

\footnotetext{
${ }^{151}$ An analogous critique has been made in the context of women's empowerment: 'Corporations have been enthusiastic in demonstrating their embrace of the SDGs, though much of this has been superficial such as boasting of female workforce participation.' Human Rights Council, 'The Parlous State of Poverty Eradication', A/HRC/44/40 (2 July 2020), para 48.

152 See, e.g., Seckinelgin, note 24, 294-97.

153 The Standards, note 4, 33-34.

${ }^{154}$ Galil, Lelis and Angelucci, note 5.
} 
recognition, protection and realization of the rights of LGBTI people. The rule of law, democratic accountability and the role of the state as guarantor require that further attention be paid to state obligations. For this same reason, actors frequently recall that the UNGPs 'should be understood as a coherent whole'. ${ }^{155}$

Advances on the SOGIESC dimensions of state duties would link in powerful ways BHR frameworks to the dynamic international LGBTI human rights agenda. A recent illustration of the persistence of the gap is that the Yogyakarta Principles 10+ and the Standards were released only weeks apart in 2017, but without any substantive overlap in process or actors. New insights could be drawn from more meaningful, sustained consideration across these divides, with particular attention to the priorities and norms that have taken shape in the international human rights framework in direct response to the advocacy of local, national and international LGBTI activists linked through diverse networks.

Third, further research is needed to understand how national and multinational business actors do and should engage with local stakeholders in the context of incorporating SOGIESC into their human rights compliance. Adopting an explicitly feminist approach, and deeper engagement with critical race theory and Third World Approaches to International Law (TWAIL) could illuminate ways for different groups and movements to create shared agendas related to gender justice. The Standards urge businesses to educate themselves on the gender contexts of the communities in which they do business ${ }^{156}$ and include local gender identities and systems in their fight against SOGIESC-based discrimination. ${ }^{157}$ Invoking James Charlton, the Standards demand 'nothing about us without us' when it comes to LGBTI rights. ${ }^{158}$ It is important for scholars, practitioners and advocates to question who the 'us' is, and to generate new insights into best practices for robust participation of rights-holders, particularly in the context of SOGIESC.

A central tenet of a human rights-based approach insists on the dignity, agency and empowerment of rights-holders as the primary benchmark against which all processes and outcomes must be assessed. The Standards reflect this: ${ }^{159}$

The application of the Standards should be guided by local stakeholders. Respecting and understanding local parameters in applying these standards will reduce the likelihood of companies taking ineffective or counter-productive initiatives. This can be achieved by actively promoting the involvement in and ownership by local stakeholders, including LGBTI civil society organizations.

Yet, as flagged above, the meanings encapsulated under 'LGBTI' do not always easily translate across cultures and contexts, and an external essentialization of LGBTI identity stands to easily replicate inequalities and discriminations.

A rights-based approach to this dimension would urge advocates and scholars to conceive of workers, consumers and community members as rights-holders rather than just 'stakeholders'. On that basis, greater attention is needed to set parameters and explore best practices for what the Standards document calls 'rights-affirming interactions"160 between businesses and local stakeholders. Any consideration of evaluation measures should prioritize input from local and national civil society and critically consider questions of representation. Operationalizing this core tenet of a human rights-based approach

\footnotetext{
${ }^{155}$ UNGPs, note $110,1$.

156 The Standards, note 4, 4 .

157 Ibid, 5.

158 Ibid, 28.

${ }^{159}$ Ibid, 13.

160 Ibid, 4.
} 
mandates a critical lens attuned to the most marginalized and vulnerable. The diversity of people affected by SOGIESC-discrimination must remain at the forefront, paying particular attention to the most marginalized.

Fourth, in terms of corporate responsibilities, more effort is needed to flesh out and advance clear human rights parameters for actions and omissions by business actors vis- $\grave{a}$-vis the human rights of LGBTI persons. Human rights responsibilities are relevant beyond harms directly related to business operations and these responsibilities should animate businesses' proactive steps to advance transformative societal change. ${ }^{161}$ As the former High Commissioner clarified when launching the Standards: 'Companies must either decide to actively combat discrimination against LGBTI people or accept that they are, in effect, facilitating it. There is no neutral position.' ${ }^{162}$

The UNWG Gender Guidance on gender-transformative measures can be applied directly to SOGIESC specific guidance as well, as illustrated by a proposed adaptation below. Further research could elaborate on the human rights responsibilities related to affirmative action and analyse the implementation of the Standards as measured by companies' efforts to:

- make public commitments to achieve substantive equality for people discriminated against on the basis of SOGIESC;

- practise rights-based empowerment of LGBTI individuals and communities;

- take measures (including affirmative action) to achieve substantive equality and eliminate all forms of discrimination;

- use their resources to combat SOGIESC-based harrassment and violence;

- engage gender- and culture-sensitive experts to evaluate the efficacy of measures taken;

- communicate regularly with rights-holders;

- collaborate with civil society organizations that have particular expertise on SOGIESC;

- sensitize decision makers about SOGIESC equality; and

- conduct advocacy for SOGIESC equality. ${ }^{163}$

At the same time, scholarship and practice must avoid losing sight of the core human rights aim of holding businesses accountable for preventing, mitigating and remedying harms directly related to their business activities. The enquiry is not one or the other. ${ }^{164}$ This lens is included in the drafting of the Standards but under-emphasized in their use to date.

Finally, the Standards call on business, academia and civil society to create the accountability mechanisms for the Standards, and this is still a pending, and pressing, task. Having a mechanism for expressions of support without accessible benchmarks or mechanisms to promote the critical review of those expressions is problematic. Businesses get the benefit of affiliating their brand with human rights, with LGBTI equality, and the UN, without any cost, risk or required contribution or change in behaviour. This gap reflects a broader systemic lack of transnational accountability mechanisms for the corporate sector. ${ }^{165}$

\footnotetext{
${ }^{161}$ See Kaeb, note 54.

162 Daniel T Bross, 'Companies Can Support LGBTI Equality by Backing the UN Standards of Conduct for Business', Partnership for Global LGBTI Equality (23 January 2020), https://www.global-lgbti.org/news-updates/companies-cansupport-lgbti-equality-by-backing-the-un-standards-of-conduct-for-business (accessed 31 October 2020).

163 Gender Guidance, note 21, 11.

164 UNGPs, note 110, 13.

165 See Nadia Bernaz, 'Conceptualizing Corporate Accountability in International Law: Models for a Business and Human Rights Treaty’ (2021) 22 Human Rights Review 45, 51-52.
} 
Deeper engagement with human rights-based benchmarks and meaning of the Standards could make them more useful to small and medium-sized enterprises outside of the Global North. For the most part, these companies are not represented among the list of Supporters and have not yet participated in transnational knowledge production regarding the Standards.

Alternative accountability is not foreign to the human rights framework, and many actors find value in the sharing of good practices and development of common language. Voluntary measures can be 'ratcheted' up. An oversight framework with a variety of benchmarks covering the full scope of the impacts and opportunities at the business and LGBTI human rights nexus would allow for more nuanced analyses. At the same time, more promising are academic and advocacy efforts to advance the elaboration of SOGIESC-specific expectation and guidance as part of deeper engagement with the gender dimensions in the UNGPs and overall BHR framework. Embedding the SOGIESC lens in existing and evolving BHR agenda points is more likely to integrate diverse rights agendas and to join critical efforts as opposed to dividing them.

\section{Conclusion}

While the LGBTI international human rights agenda and UNGPs have evolved in parallel and overlapped in time by coincidence at several key points, these two critical agendas have seen little to no substantive convergence.

The Standards are the most important effort at this nexus, and they emerged as part of an effort to maximize the potential of multinational corporations headquartered in the Global North to contribute to positive social change towards LGBTI equality. The Standards were drafted with clear links to the international human rights framework and offer important linchpins for advancing a more robust, rights-based consideration of SOGIESC dimensions through a BHR framework applied to businesses regardless of size, location or industry.

Thus far, the Standards have been primarily an object of interest for CSR circles, and they have been evolving mostly untethered to the international human rights framework. Nonetheless, the existence of the Standards has seemingly occupied the place of proxy, a 'checkmark in the SOGIESC box', which has diverted attention from the still pending need to meaningfully incorporate dimensions of SOGIESC into BHR frameworks as a cross-cutting priority.

The UNWG's 2021 'UNGPs10+' Project aims to 'develop an ambitious vision and roadmap for implementing the UNGPs more widely and more broadly between now and 2030.'166 Explicitly including SOGIESC dimensions, and the harms that are disparately and differentially experienced by LGBTI people, should be among the priorities for scholars, policy-makers, practitioners and advocates working to advance this ambitious vision. Further research and engagement with the Standards can contribute to this project.

This article has set out areas deserving of greater attention in terms of advancing a robust, human rights-based approach to the Standards and a more expansive consideration of SOGIESC in BHR frameworks. The most essential component of human rights are the rights-holders. For work to truly be at the nexus of business, human rights and SOGIESC, it must centre the experience, agency and claims of the people in whose name these projects are pursued. In this, priority must be given to those most marginalized by the structures of discrimination and violence our efforts seek to transform.

Conflicts of interest. The authors declare none.

\footnotetext{
${ }^{166}$ Office of the High Commissioner for Human Rights, 'UN Guiding Principles on Business and Human Rights at 10', https://www.ohchr.org/EN/Issues/Business/Pages/UNGPsBizHRsnext10.aspx (accessed 7 May 2021).
} 